\title{
Applied spatial analytic tools in orchards with special regard to agro-ecology
}

\author{
Fórián, T. ${ }^{1}$, Nagy, A. ${ }^{1}$, Tamás, J. ${ }^{1}$, Szabó Z. ${ }^{1}$, Soltész, M. ${ }^{2} \&$ Nyéki, J. ${ }^{1}$ \\ ${ }^{1}$ University of Debrecen, Centre of Agricultural Sciences and Engineering, Faculty of Agricultural and Food \\ Sciences and Environmental Management, Institute of Water and Environmental Management, H-4032 Debrecen, \\ Böszörményi 138, Hungary, tamas@gisserverl.date.hu \\ ${ }^{2}$ Collage of Kecskemét, Faculty of Horticulture, H-6000 Kecskemét, Erdei Ferenc tér 1-3.
}

\begin{abstract}
Summary: Our investigation was carried out in several orchards in Hungary. This study reviews applicability of the different spatial analytical techniques in orchard especially models based on surface relief, such as digital elevation model, digital terrain model, slope and aspect maps. In recent time, the generation of digital elevation model has become a popular examination method. However, the elevation models generated from contour lines or elevation points could be applied to evaluate agro- ecological potential of fruit orchards to some extent. The highest deficiency of these models is the fact that these show the altitude of soil surface only and do not demonstrate landmarks on the surface. Consequently, the calculation of the radiation value results data relating to soil surface. The terrain model generated and applied by our team demonstrates fine surface texture and the landmarks in the orchard, so it is suitable for further examination.
\end{abstract}

Key words: digital elevation model, aspect, slope, solar radiation

\section{Introduction}

Nowadays the applied geoinformatical techniques, the environmental modelling are one of the most typical sourcemanagement applications. To predict the effect on soil and yield we have to create a complex model. These questions could be answer efficiently with the help of the geographical information systems and the decision support systems based on geoinformatics (Németh et al., 2007). Neither best model can result suitable data if the input data base has poor quality or is inadequate. The data quality is determined by data collection and examination methods. The precision agriculture and the different technological elements of it become general better in the field of the crop production all over the world and also in Hungary (Tamás, 2001). At the same time manly experimental applications were taken place in case of fruit production in Hungary (Firtha, 2006). In course of history of digital elevation modelling significant results have given out considering differences in relief (Dobos et al., 1998; 2000). In geoinformatics more or less detached sector examines the questions of the surface modelling (Moore et al., 1993; Florinsky and Kuryakova, 1998; Wilson and Gallant 1998).

From our examination fields high resolution digital elevation or terrain model were not generated earlier. The surface model of MoD Mapping Company has $5 \mathrm{~m}$ resolution, which is unsuitable for solution of the problem of the precision agriculture and water-management in fruit production parcels. Our data base also contained topographic maps, true-colour airborne images and field surveys data, and supporting data about fruit tree sub-species.

\section{Material and methods}

We used the topographical maps with 1:10.000 scale in EOV coordinate system for the vectorization. The methods used survey point elevations and contour lines digitised from existing maps also to describe terrain surface. The handicap of the above mentioned secondary data collection is that occasionally more decades could pass between the mapping and the processing work. On the other hand, the original geodesic survey's error extension inside the segment or the fotogrammetrical error extension's dispersion surface is not known. This shows an unidentifiable random dispersion below the accepted limit of error. In our case this could have been compensated that the limit of error was $<1 \mathrm{~m}$ which also in the case of precision techniques could be viewed as an outstanding good result. On the digital data we carried out filtering to separate the elevation point without value. On the basis of prepared data base five different interpolation methods were compared with each other. The examined methods were as follows: Kriging, Global Polynominal- GP, Local Polynominal Interpolation- LP, Inverse Distance Weighted- I DW, and Radial Basis Functions- RBF. The descriptions of these methods are found in several works (Isaaks and Srivastava 1989). For the agro-hydrology down flow / gathering method we evaluate the data after spline approximation measures. The surfaces are created using ArcGis 9.2 sofware 3D Analyst extension.

We have performed primary field work, which were concerned to spatial and attributive data. In the case of spatial data we used Trimble Juno PDA with integrated GPS, or rather DGPS correction in Terrasync Office environment on 


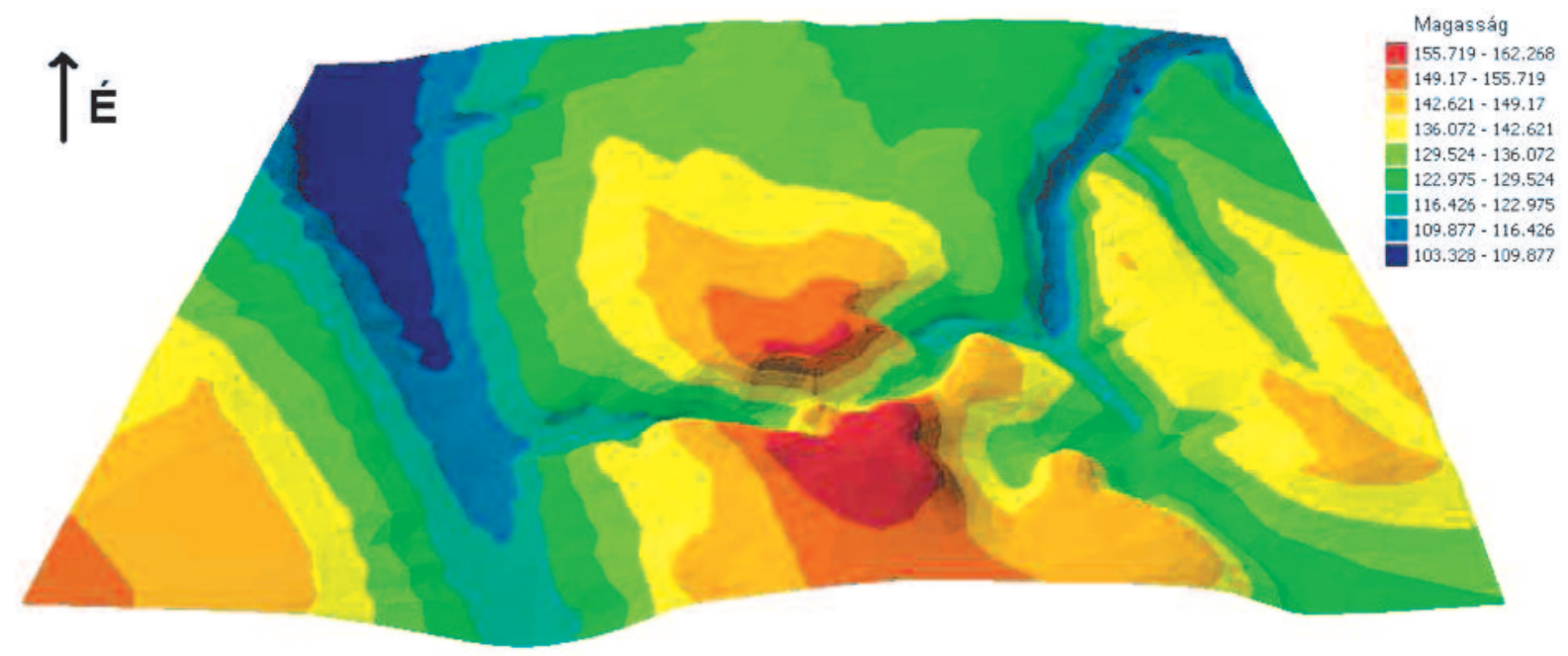

Figure 1: The TIN model of the orchard at Siófok in 3 dimension view

the basis of the Trimble Pathfinder geostation archives. The real time field work was applied with processing of MobileGIS ArcPad 8 and Digiterra 6 software's. The height and width of trees were defined with the help of Leica Distro 8 laser distance meter and the measure wheel $(2 \mathrm{~cm}$ precision).

To measuring of the soil water-management parameters the punctiform samples supplied data on the basis of scientific literature.

Our investigation was carried out in several orchards in Hungary, for examples the genetic collection of pomaceous fruits (apple, pear, quince, medlar) at Újfehértó; pear plantations near Nagykanizsa, and peach orchard at Siófok. These areas have very different relief parameters. The plantation at Újfehértó consists of fixed sand dunes accordingly the relief is heterogeneous, but lowland type. However the orchards at Siófok and Nagykanizsa are situated on hilly region, consequently have higher elevation differences.

\section{Result and discussion}

The applied 3D Analyst extensions are useful to create TIN or raster models. The TIN models are often best visualized as 3 dimension surfaces, which an array of triangular areas (Figure 1). Their corners defined by known elevation points with great importance. Compared to the Grid model, the TIN model is relatively cumbersome to establish but more efficient to store because areas of terrain with little detail are described with less data than similar areas with greater variation. The surface runoff characteristic calculations are most expediently performed using a TIN model (Bernhardsen, 1992) or a raster surface. Water flows across a surface always in the steepest downslope direction. Once the direction of flow out of each cell is known, it is possible to determine which and how many cells flow into any given cell. After running the Flow Direction function an raster map is created showing a value of the change in
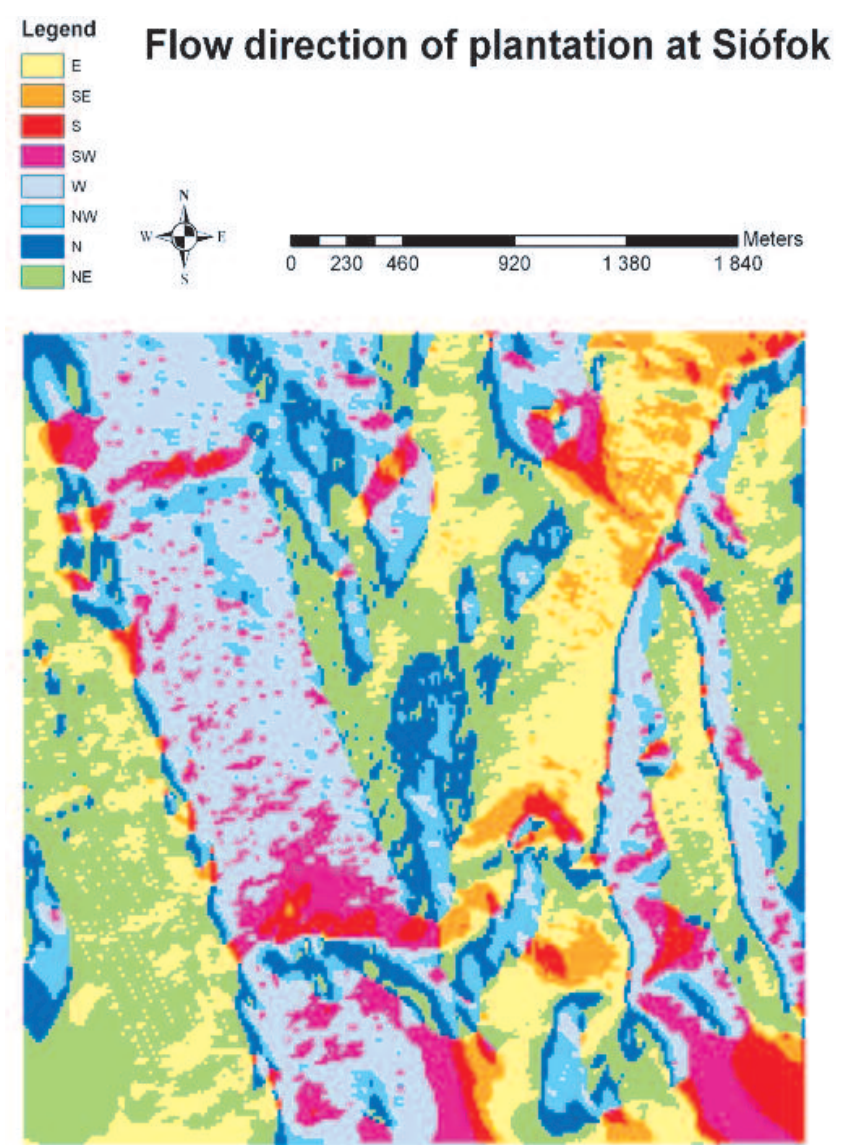

Figure 2: The flow direction map of the orchard at Siofok

elevation from each cell along the direction of flow to the path length between centers of cells (Figure 2).

For the agro-ecological examination of the fruit plantations there is need to derive new raster surfaces from an elevation model including slope, aspect or hillshade tools. These raster data are suitable to generate other analysis, as well as visualization too. These methods result itemized statements from main surface characteristics of every parcel in order to design new building investments or further plantations (Figure 3). 


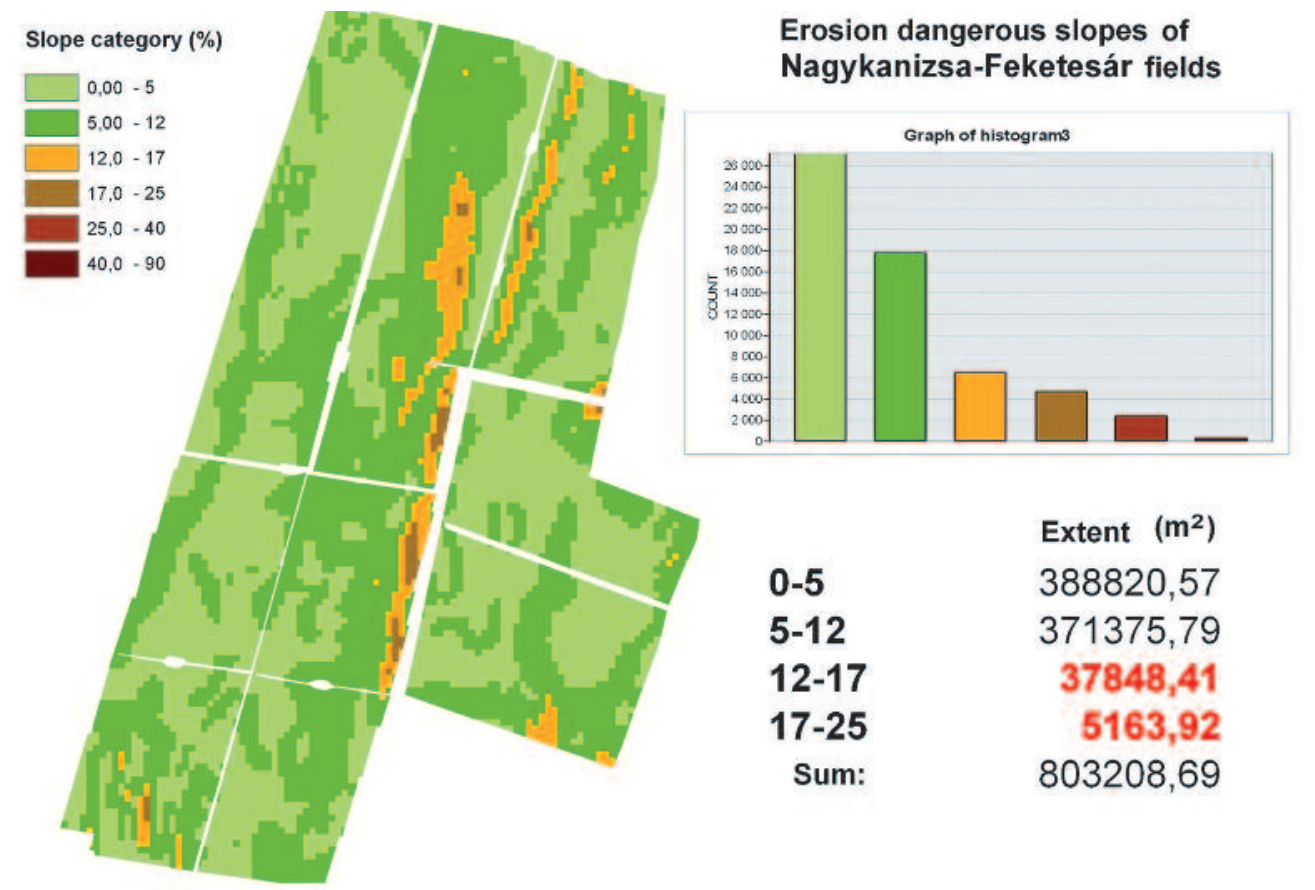

Figure 3: The slope categories of parcels at Nagykanizsa

The highest deficiency of these models is to the fact that these show the altitude of soil surface only and do not demonstrate landmarks on the surface, so the calculation of the direct radiation value results data relating to soil surface. Consequently, we have to give attention to the landmarks for the agro-ecology examination such as solar radiation calculation. After creation of the terrain model by complicated mathematical operations, which contains the fruit trees, and artificial objects also, we could operate solar radiation toolset. These tools are useful to measure the amount of solar radiation in watt hours per square meter on a specified area or a point location. There are several configuration variables to define the time period of the examination, from one point of time to one year period. The potential evapotranspiration could be estimated with adequate precision from the derived maps.

\section{Conclusion}

Next future these methods can help effectively to intensify precision fruit production. On the basis of above mentioned results, the TIN / raster model combination is well suitable for evaluation and examination of high continuous areas. The Horton-Strathler model results valid value regarding to hilly or mountainous regions, while the convexity examinations give only suitable value under high data density to lowlands.

\section{Aknowledgement}

Research was sponsored by NFÜ TECH_08-A3/22008-0373 AND TECH_08-A4/2-2008-0138 grants.

\section{References}

Bernhardsen, T. (1992): Geographic Information System. Viak IT, Norwegian Mapping Authority, Arendal, Norway, 65-71.

Dobos, E. (1998): Quantitave analysis and evaluation of AVHRR and terrain data for small scale soil pattern recognition. PhD Thesis, Purdue University, West Lafayette, IN, USA

Dobos, E., Micheli, E., Baumgardner, M. F., Biehl, L. \& Helt, T. (2000): Use of combined digital elevation model and satellite radiometric data for regional soil mapping. Geoderma. 367-391.

Firtha, F. (2006): Controlling and calibration of hyper-spectral measurement, Journal of Food Physics, Budapest, 17-18: 13-28.

Florinsky, I. \& Kuryakova, G. (1998): Determination of grid size for digital terrain models in soil investigations. Proceedings of the 16th World Congress of Soil Science. Montpellier, France Isaaks, E. H. \& Srivastava, R. M. (1989): An Introduction to Applied Geostatistics. Oxford Press, New York. 560.

Moore, I. D., Gessler, P. E., Nielsen, G. A. \& Peterson, G. A. (1993): Soil attribute prediction using terrain analysis. Soil Sci. Soc. Am. J., 57: 443-452.

Németh, T., Neményi, M. \& Harnos, Zs. (2007): Methodology of Precision Agriculture (in Hungarian) JATE Press., 1-238.

Tamás, J., (2001): Precision agriculture (in Hungarian), Szaktudás Kiadó, Budapest, 160. p.

Wilson, J. P. \& Gallant, J. C. (1998): Terrain-based approaches to environmental resource evaluation. In: Lane, S. N., Richards, K. S., Chandler, J. H. (eds.) Landform Monitoring, Modelling and Analysis. New York,Wiley. 219-240. 